\begin{tabular}{lc}
\hline CURRENT & ISSN: 0973-4929, Vol. 14, No. (3) 2019, Pg. 458-462 \\
WORLD & Current World Environment
\end{tabular}

ENVIRONMENT

www.cwejournal.org

\title{
Estimation of Biogas Loss in Non-Working Plants and Finding Association between Biogas Plants and Dung Availability in Chhattisgarh, India
}

\author{
KUMAR SHAILENDRA*1 and SINGH NEELAM KUMAR ${ }^{2}$ \\ ${ }^{1}$ Department of Agricultural Engineering, BNPG College, Rath, Hamirpur (UP) India. \\ ${ }^{2}$ Department of Agricultural Statistics, BNPG College, Rath, Hamirpur (UP) India.
}

\begin{abstract}
Present study deals with the situation and phenomenon of biogas plants being under working and non-working conditions in Chhattisgarh state, India. The characteristic of working and non-working biogas plants is a continuous birth and death like process which is dynamic in nature. The non-working plants are rare in large domain of biogas plants established. The dynamic characteristics of working and non-working biogas plants follow some rule of path or probability distribution. Therefore, an attempt has been made in the study to estimate loss of biogas energy because of non-working biogas plants and unused dung in the given domain of Chhattisgarh state. The data of working and non-working biogas plants was collected by using appropriate sampling technique and biogas loss is estimated. Biogas loss due to non-working biogas plants was estimated to be $10491 \mathrm{~m}^{3} /$ day. Biogas loss due to unused dung was estimated as $2570835 \mathrm{~m}^{3}$ /day. Rank correlation coefficient between dung availability and established biogas plants is found to be 0.05057 . It indicates that the dung availability is not associated with establishment of biogas plants but some other reason such as environmental awareness, education and technological know how are responsible for establishment of biogas plants.
\end{abstract}

\section{Introduction}

It is an era worldwide which attracts the attention of scientists, policy makers and the society to discover alternative source of energy which is sustainable and is associated with man, animal and nature. Animal rearing practices are essential component of life where there is strong interdependent between cow and man in rural India. Cow generates energy not

CONTACT Kumar Shailendra $\$ shailendrakgangwar@gmail.com 9 Department of Agricultural Engineering, BNPG College, Rath, Hamirpur (UP) India.

\section{(c) (9)}

(c) 2019 The Author(s). Published by Enviro Research Publishers.

This is an Open Access article licensed under a Creative Commons license: Attribution 4.0 International (CC-BY).

Doi: http://dx.doi.org/10.12944/CWE.14.3.13 
only in the form of nutrients such as milk but also provides bullock energy and dung. It is dung which is source of renewable energy in the form of biogas, dung cake.

Benerjee (1996) reported that biogas was a clean and particulate free source of energy, reduced the livelihood of chronic diseases that are associated with the indoor combustion of biomass based fuels such as respiratory functions, ailments of lungs, bronchitis, asthma, lung cancer and increased severity of coronary artery disease.

India has initiated several plans towards biogas plants to be established into the villages providing high subsidy. But, unfortunately, there are several plants which are in non- working conditions and the available extra dung is not properly converted into biogas energy.

In Chhattisgarh state (CG), the installation of biogas plants are carried out by the Chhattisgarh Renewable Development Agency (CREDA), Government of CG from 25th May 2001. Yearly, statistical data of CG State indicates that the biogas plants are getting popularity among the farmers of CG (Kumar S, et.al., 2015). The total numbers of biogas plants installed by CREDA in the Chhattisgarh state were found to be 30,376 till year 2010 and on an average more than three thousand (3375) plants are added annually (Kumar Shailendra et.al., 2016). But number of non- working plants is not known annually.

The non active plants are the great loss to the society as heavy investment does not procure any material benefit but working plants gave manifold benefits to the society for long time (Kumar S, 2013). Therefore need arose to study the consequential loss of biogas because of plants being in non-working condition. The exact number of non-working plants can not be known but can be estimated assuming that biogas plants being in non-working condition is like birth and death phenomenon in large during passage of time. This fallows negative bionomial distribution. The interest of the present study is to estimate loss of biogas due to biogas plants being in non-working conditions. The study was also undertaken to estimate the total dung availability and potential biogas plants that can be established is also estimated.

\section{Material and Methods}

A multistage sampling from the districts of Chhattisgarh state (CG) was carried out during 2007-08. From few selected districts, few villages were selected from few selected blocks. To estimate the non-working plants, an inverse sampling methodology was followed so that the number of non- working plants were fixed as $\mathrm{n}_{1}=18$ plants. To get 18 non- working plants, total 117 plants were observed. In this case, $\mathrm{n}_{1}$ is fixed and total sample size, $n=117$ plants were random. Assuming, the number of plants are large in number, it follows a negative binomial distribution.

Let $p$ is the probability of non-working plants so that $\mathrm{Np}$ plants are non-working condition and $\mathrm{Nq}$ are in working condition so that $\mathrm{Np}+\mathrm{Nq}=\mathrm{N}$. Let $\mathrm{n}_{1}$ plants are in non-working conditions from the random sample size $\mathrm{n}$ which not fixed in advance but is a random variable. Therefore,

$$
p(n)=\frac{C_{n_{1}-1}^{N p} * C_{n-n_{1}}^{N q} * \frac{N p-n_{1}+1}{N-n+1}}{C_{n-1}^{N}}
$$

Where, $n=n_{1}, n_{1}+1, n_{1}+2, n_{1}+3, n_{1}+4, \ldots \ldots \ldots, n_{1+}$ Nq.

We can see that $p=\left(n_{1}-1\right) /(n-1)$ is an unbiased estimate of $p$.

Thus, if total number of biogas plants established $=\mathrm{N}$, then total non-working biogas plants will be estimated as N.p and estimated working plants will be N.q, where $q=1-p$. From this estimated working plants of biogas in the state, we can estimate the total number of potential biogas plants in the Chhattisgarh (CG) state. For this estimated working biogas plants, we require some fixed amount of dung.

Now, there are extra dung available (only from cow family) from the state that can be potential energy to be harnessed from more biogas plants which is interest of the present study. We can see that extra dung available $=$ Total available dung, $\mathrm{kg} /$ day - dung required for estimated working biogas plants.

There is presumption that the districts having high ranking in dung availability would be associated with the rank of biogas plants availability in the districts 
of the CG state. Rank correlation coefficient is used to study and to interpret above assumption. The ranking of dung availability of the CG state and ranking of biogas plants availability was done for consecutive districts.

Here, difference of rank of the ith district $=d i$, Where, $i=1,2,3,-------n$ and $n$ is number of districts.

Rank correlation between dung availability and number of existing biogas plants in different districts is measured by using formula given as below:

$$
r_{R}=1-\frac{6 \sum_{i=1}^{n} d_{i}^{2}}{n\left(n^{2}-1\right)}
$$

\section{Results}

From the Table 1, the 'p' i.e. probability of nonworking plants is found to be 0.146 . Let total number of plants in the CG state is N. Thus, in CG state, there are estimated number of non- working plants as $N . p=3497$ and number of estimated biogas plants in working conditions as $\mathrm{N} . \mathrm{q}=20442$. Where $\mathrm{N}=$ 23953 and $q=1-p$.

Table 1: District wise Dung availability and sample observations of working and non-working biogas plants

\begin{tabular}{lccc}
\hline S. No. & Sampled District & $\begin{array}{c}\text { Number of non-working plans } \\
\text { in the sample of the village }\end{array}$ & $\begin{array}{c}\text { Number of working plants } \\
\text { in the sample of the village }\end{array}$ \\
\hline 1 & Raipur & 02 & 10 \\
2 & Mahasamund & 0 & 10 \\
3 & Dhamatari & 0 & 6 \\
4 & Durg & 4 & 8 \\
5 & Rajnandgaon & 0 & 5 \\
6 & Kawardha & 0 & 7 \\
7 & Bilaspur & 3 & 6 \\
8 & Koraba & 1 & 5 \\
9 & Raigarh & 2 & 16 \\
10 & Jangir-Champa & 5 & 15 \\
11 & Surguja & 1 & 11 \\
Total & & 18 & 99 \\
\hline
\end{tabular}

Therefore, total dung required for 20442 working biogas plants is $1533198 \mathrm{~kg} /$ day. Still, there is extra unused dung (from cow family) as $64270914 \mathrm{~kg} /$ day for an average size of biogas plants as $3 \mathrm{~m}^{3}$. We have potential biogas plants which can be established as 856945 of size $3 \mathrm{~m}^{3}$. Potential biogas which can be procured by unused dung will be $2570835 \mathrm{~m}^{3} /$ day.

Dung required for biogas plant of size one $\mathrm{m}^{3}$ is $25 \mathrm{~kg} /$ day (Rai, 1997). The huge amount of dung is used either as a dung cake or manure. The potential biogas which could have been high source of renewable energy by unused dung is not harnessed but unused dung is transformed into dung cake energy that create environmental pollution and health hazard to the society.

Table 2 indicates that the rank correlation coefficient between dung availability and number of total existing biogas plants is found to be 0.05057 . This indicates that high dung availability is not only the sufficient factor for biogas plants establishments. 
Table 2: Rank between dung availability and existing biogas plants of districts of CG state

\begin{tabular}{|c|c|c|c|c|c|c|c|}
\hline $\begin{array}{l}\text { S. } \\
\text { No. }\end{array}$ & District & $\begin{array}{l}\text { Total Dung } \\
\text { Available, } \\
\text { Kg/Day }\end{array}$ & $\begin{array}{l}\text { Existing Biogas } \\
\text { Plants, Nos. }\end{array}$ & $\begin{array}{l}\text { Rank of dung } \\
\text { availability(x) }\end{array}$ & $\begin{array}{l}\text { Rank of existing } \\
\text { biogas plants(y) }\end{array}$ & $d=x-y$ & $d^{2}$ \\
\hline 1 & Raipur & 7888052 & 2301 & 17 & 16 & 1 & 1 \\
\hline 2 & Mahasamund & 3000988 & 4718 & 9 & 18 & -9 & 81 \\
\hline 3 & Dhamatari & 2017576 & 1782 & 4 & 14 & -10 & 100 \\
\hline 4 & Durg & 6620488 & 1103 & 16 & 8 & 8 & 64 \\
\hline 5 & Rajnandgaon & 4916260 & 1336 & 14 & 11 & 3 & 9 \\
\hline 6 & Kawardha & 1921608 & 546 & 3 & 4 & -1 & 1 \\
\hline 7 & Bilaspur & 4170168 & 1333 & 13 & 10 & 3 & 9 \\
\hline 8 & Koraba & 350988 & 856 & 1 & 7 & -6 & 36 \\
\hline 9 & Raigarh & 2691836 & 2317 & 7 & 17 & -10 & 100 \\
\hline 10 & Jangir-Champa & 2842516 & 1308 & 8 & 9 & -1 & 1 \\
\hline 11 & Surguja & 1420008 & 1424 & 2 & 13 & -11 & 121 \\
\hline 12 & Jaspur & 5352776 & 584 & 15 & 5 & 10 & 100 \\
\hline 13 & Korea & 3118176 & 351 & 10 & 3 & 7 & 49 \\
\hline 14 & Baster & 2130536 & 1366 & 6 & 12 & -6 & 36 \\
\hline 15 & Kanker & 8246912 & 1783 & 18 & 15 & 3 & 9 \\
\hline 16 & Dantewada & 2110464 & 752 & 5 & 6 & -1 & 1 \\
\hline 17 & Narayanpur & 3446220 & 80 & 11 & 2 & 9 & 81 \\
\hline \multirow[t]{2}{*}{18} & Bijapur & 3558540 & 13 & 12 & 1 & 11 & 121 \\
\hline & Total & 65804112 & 23953 & & & & 920 \\
\hline
\end{tabular}

\section{Conclusion}

From the above discussion and analysis, it is evident that we have high scope and potentiality of biogas energy to be harnessed in future to meet the needs of the rural India. There is need of innovation and policy formulation by the state to harness this component energy to be explored. Further, the non- working plants can be activated to meet the requirements of renewable energy with low cost and extra dung unused can be a high potential energy in rural India in the form of biogas.

The rank correlation coefficient between districts for the characters such as dung availability and number of total existing biogas plants is found to be insignificant. This implies that availability of dung is not a strong deciding factor for acceptance of biogas plants in the society but there would be other reason such as education, environmental awareness, technical know how and social awareness of the farmers, which requires attention by policy makers and administration.

\section{Acknowledgement}

We acknowledge to IGKV, Raipur for providing all the facilities to conduct survey work and CREDA. We also thank to Dr. B P Mishra, Professor (Rtd), Faculty of Farm Machinery, IGKV, Raipur for his valuable advices.

\section{Funding}

The author(s) received no financial support for the research, authorship, and/or publication of this article.

\section{Conflict of Interest}

The authors do not have any conflict of interest. 


\section{References}

1. Benerjee, S,. 1996. The enemy within. Down to earth. Vol. 5, No. 4, pp 27-32.

2. Kumar Shailendra, B. P. Mishra, M. S. Khardiwar, S. K. Patel and F.G. Sayyad, 2015. Economic evaluation of different Size of Biogas Plants in Chhattisgarh (India). Current World Environment, An International Research Journal of Environmental Science, ISSN: 0973-4929, Online ISSN: 2320-8031, .Vol. 10(1), pp. 184-188 (2015).

3. Kumar Shailendra, B. P. Mishra, M. S. Khardiwar,S. K. Patel, B. K.Yaduvanshi and B. P. Solanki, 2016. Biogas Plants in Chhattisgarh (India): A Case Study.
Current World Environment, An International Research Journal of Environmental Science, ISSN: 0973-4929, Online ISSN: 2320-8031,. Vol.11(2), pp. 599-603 (2016).

4. Kumar, Shailendra 2008. Techno-Economic Study of Biogas Plants In The Chhattisgarh plain. M.Tech. Unpublished thesis, IGKV, Raipur, (Chhattisgarh) India of biogas plants' adoption in Chhattissgarh, India. Spring, 2013, 2(2), 10-13.

5. Rai, G. D. 1997. Non-Conventional Energy Sources. Khanna Publishers Pvt. Ltd. New Delhi, India: pp 311-435. 